\title{
Comparative study of oral PGE 1 and intracervical PGE2 gel for pre- induction cervical ripening in prelabour rupture of membranes $>37$ weeks gestational age
}

\author{
Alka N. Nadar, Sirisha P. S. R. N. S.* \\ Department of Obstetrics and Gynecology, Sri Ramachandra Medical College, Chennai, Tamil Nadu, India \\ Received: 15 February 2018 \\ Accepted: 09 March 2018 \\ *Correspondence: \\ Dr. Sirisha P. S. R. N. S., \\ E-mail: sirishapjr@yahoo.co.in \\ Copyright: (C) the author(s), publisher and licensee Medip Academy. This is an open-access article distributed under \\ the terms of the Creative Commons Attribution Non-Commercial License, which permits unrestricted non-commercial \\ use, distribution, and reproduction in any medium, provided the original work is properly cited.
}

\begin{abstract}
Background: Active induction of labour in prelabour rupture of membranes resulted in a lower risk of maternal and fetal sepsis as compared to conservative management. Pre-induction cervical ripening helps in successful induction of labour.in this study we have compared the efficacy of low dose $25 \mathrm{mcg}$ oral misoprostol versus intracervical PGE2 gel for cervical ripening in term PROM patients.

Methods: Women with pregnancies between 37 and 41 weeks gestational age presenting with PROM at term and a Bishop score of 4 or less were randomly assigned to receive either a 25 -mcg oral misoprostol every 4-hourly interval or 3 applications of intracervical PGE2 gel at a 6-hour interval for effective cervical ripening. Oxytocin was initiated if labor had not started after 6 hours of last effective dose of prostaglandin.

Results: Fifty-three women $(75.73 \%)(n=70)$ in the oral misoprostol group with 2 doses, 4 hours apart had successful cervical ripening within 8 hours in comparison to sixty-two women $(88.58 \%)(\mathrm{n}=70)$ in the intracervical PGE2 gel group with 2 doses, 6 hrs apart approximately 12 hrs for successful ripening. $(\mathrm{p}=0.021)$. Oral misoprostol group needed shorter mean duration interval for the Bishop score $<4$ to $>6$ than intracervical PGE2 gel group, $7.84 \pm 3.64$ hours and $9.39 \pm 4.20$ hours respectively $(\mathrm{p}=0.022)$. Similarly, the mean time duration interval from ruptured membranes to vaginal delivery in oral misoprostol was shorter i.e. $12.60 \pm 3.78$ hours versus $14.66 \pm 4.08$ hours $(\mathrm{p}=0.005)$.

Conclusions: Low dose $25 \mathrm{mcg}$ oral misoprostol is a safe, efficacious and better tolerated alternative to intracervical PGE2 gel for pre-induction cervical ripening in especially in PROM patients at term.
\end{abstract}

Keywords: IOL, Oral Misoprostol, Pge2 gel, PROM

\section{INTRODUCTION}

Prelabour rupture of membranes is spontaneous rupture of membranes any time beyond 28thwk of pregnancy but before the onset of labor. Term PROM refers to ROM at or $>37$ weeks GA. PROM occurs in approximately 5$10 \%$ of all pregnancies. ${ }^{1}$ Active induction of labour in prelabour rupture of membranes resulted in a lower risk of maternal and fetal sepsis as compared to conservative management.

Following methods have been traditionally used for management of labour in term PROM patients.

- Expectant management

- Induction with i.v. oxytocin 
- Pre-induction cervical ripening with vaginal PGE2 gel / vaginal PGE1 tablets/oral PGE1 tablets.

Women with active interventions had a shorter PROM to delivery interval and hence was preferred by the patients. ${ }^{2}$ When the cervix is unfavourable, induction attempts may fail, resulting in prolonged labour and caesarean delivery. ${ }^{3}$ Cervical ripening is defined as a change in Bishop score from $<4$ to $>6$.

Prostaglandin E2 (PgE2) gel, given vaginally or intracervically, has been shown to be effective for cervical ripening. ${ }^{4}$ Misoprostol, a prostaglandin E1 analogue, initially manufactured for the management of gastric ulcers, has also been evaluated as a cervical ripening agent. Misoprostol is inexpensive, stable at room temperature, easy to administer unlike PGE2 gel which requires refrigeration.

Various systematic reviews of randomized controlled trials evaluating the use of oral misoprostol for cervical ripening, suggesting that misoprostol is effective, but there is concern that misoprostol may increase the rates of tachysystole and hyperstimulation. ${ }^{5}$ In most trials vaginal route has been chosen, because of a longer halflife when administered vaginally than orally. ${ }^{6}$ However the short half-life of oral misoprostol may be an advantage for cervical ripening, because of less risk for hyperstimulation and tachysystole.

The advantage of misoprostol orally with particular reference to PROM, is avoidance of repeated vaginal examinations resulting in less risk of sepsis for the both mother and baby. ${ }^{7}$

Although dinoprostone (PGE2) has been approved by the US Food and Drug Administration (FDA) for cervical ripening in women at term, misoprostol was not approved for such use by the FDA until 2002. ${ }^{9}$ The practice bulletin and committee opinion from the American College of Obstetricians and Gynecologists suggested that misoprostol for labor induction should be administered as a $25-$ mcg dose vaginally every $4-6$ hours. ${ }^{10}$ We have taken up this study to compare intracervical PGE2 gel and low dose $25 \mathrm{mcg}$ oral misoprostol for cervical ripening in term PROM patients.

The aim of this study is to compare the effectiveness, safety, and tolerance of each dose of $25 \mathrm{mcg}$ oral misoprostol (maximum of 4 such doses at 4 hourly interval) for pre induction cervical ripening with $0.5 \mathrm{mg}$ intracervical PGE2 gel maximum of 3 doses each at 6 hourly interval, in women with PROM at or $>37$ weeks gestational age with bishop score <4 (unfavourable cervices.)

The primary objective in this trial is to study and see if each dose of $25 \mathrm{mcg}$ oral misoprostol (maximum of 4 such doses at 4 hourly interval) in comparison to each dose of $0.5 \mathrm{mg}$ PGE2 gel intracervically (maximum of 3 doses at 6 hourly interval) is more efficacious in pre induction cervical ripening in term PROM with <4 bishop score.

The other secondary outcome measures that would be studied are

- PROM to successful cervical ripening interval (bishop score $>4$ )

- Number of doses required for successful cervical ripening

- PROM to delivery interval

- Need for oxytocin augmentation

- Mode of delivery

- Maternal and neonatal outcome.

\section{METHODS}

Induction and labor ward, Sri ramachandra medical college all PROM pts at or $>37$ wks GA, primigravida / multigravida admitted from December 2014 to October 2016 as per selection criteria mentioned below.

\section{Inclusion criteria}

- Singleton pregnancy with cephalic presentation

- Gestational age at or $>37$ weeks

- Spontaneous PROM confirmed by history and examination

- Admission to labor room within 6 hours of PROM and bishop score $<4$

- Patient not in active labour.

\section{Exclusion criteria}

- PROM before 37 completed weeks or patient in active labor

- Features of chorioamnionitis

- Meconium stained liquor, congenital malformation of fetus, non-reactive CTG

- Medical or obstetric complications like placenta previa, previous LSCS, PIH, GDM, MULTIPLE PREGNANCY

- Any contraindication to prostaglandin use like bronchial asthma.

\section{Method}

All primigravida/multigravida, admitted with PROM at or $>37$ weeks GA and bishop score $<4$ fulfilling the inclusion criteria included in the study. Rupture of membranes detected by seeing a pool of amniotic fluid in speculum examination and a reactive cardiotocographic trace. A high vaginal swab was taken for direct microscopy, gram staining and culture. Vaginal examination was performed under sterile conditions to assess the initial Bishop score. Informed written consent were taken from the patients. Institute Ethical committee clearance was obtained prior to the study. 


\section{Design}

\section{Non-blinded randomized clinical trial comparison.}

After full informed consent, women were randomly assigned to receive oral misoprostol or intracervical PGE2 gel by means of a computer-generated table of random numbers. The randomization assignments were placed into opaque, sealed envelopes. The study patients will be randomly allocated to one of the two groups.

\section{Group A}

25 mcg oral misoprostol tablets were given every 4-hour interval with maximum of 4 such doses, in case if the study patient fail to response to the 4 th dose i.e Bishop score $<6$ the case is said to be a failure.

\section{Group B}

$0.5 \mathrm{mg}$ PGE2 GEL maximum of 3 doses every 6-hour interval is to be given till the bishop score is $>6$. If bishop score is $<6$ even after the 3 rd dose the study case is said to be a "failure". In both the groups uterine contractions, fetal heart rate pattern, presence of vomiting, diarrhea and fever were monitored.

Oxytocin augmentation was used once the cervical ripening was successful. Sign of chorioamnionitis were watched for. Uterine tachysystole is defined as six or more contractions in 10 minutes for two consecutive 10minute periods and hyperstimulation as tachysystole associated with abnormal fetal heart recording necessitating immediate delivery or tocolytics. During the labour if any abnormal labour pattern or abnormal fetal heart rate pattern was noted immediately delivered by emergency ceasarean section.

\section{Sample size and its justification}

We evaluated a pilot study in that we got a risk difference as 0.23 . According to that sample size calculation was done. A sample size of 60 (in each arm) will be sufficient to detect a clinically significant difference between oral misoprostol versus intra cervical PGE2 gel. The success rate of oral misoprostol and intra cervical PGE2 gel is $70 \%$ and $45 \%$ as found from pilot study. Assuming $80 \%$ power and $5 \%$ level of significance. This number has been increased to 70 (in each arm). Statistical analysis was performed by the statistical software STATA 11.0. Chi-square test or Fisher's exact tests were used to assess differences in categorical data. Student Unpaired T-test was used for differences in means of two normally distributed independent data. The $\mathrm{p}$ value of $<0.05$ was considered as significant.

\section{RESULTS}

The number of patients in the age group 25-28 years is comparable between the two-study group suggesting that no age incidence bias was expected.

Table 1: Age wise distribution.

\begin{tabular}{|lll|l|}
\hline $\begin{array}{l}\text { Age } \\
\text { (years) }\end{array}$ & $\begin{array}{l}\text { Nroup A } \\
\text { Oral } \\
\text { misoprostol }\end{array}$ & $\begin{array}{l}\text { Group B } \\
\text { Intracervical } \\
\text { PGE2 gel }\end{array}$ & $\begin{array}{l}\text { P- } \\
\text { value }\end{array}$ \\
\hline $21-24$ & $6(8.57)$ & $10(14.28)$ & \\
\hline $25-28$ & $42(60)$ & $41(58.57)$ & 0.495 \\
\hline $29-32$ & $19(27.14)$ & $16(22.85)$ & \\
\hline More than 32 & $2(2.85)$ & $4(5.71)$ & \\
\hline Mean (SD) & $27.33(2.76)$ & $27.11(3.48)$ & \multirow{2}{*}{0.687} \\
\hline Range & $22-34$ & $21-41$ & \\
\hline
\end{tabular}

Test-chi square test

Both the groups had comparable number of primigravida and multigravida.

Table 2: Parity incidence.

\begin{tabular}{|lllll|}
\hline Group & $\begin{array}{l}\text { Group A } \\
\text { oral } \\
\text { misoprostol }\end{array}$ & $\begin{array}{l}\text { Group b } \\
\text { intracervical } \\
\text { PGE2 gel }\end{array}$ & $\begin{array}{l}\text { Total } \\
\text { N }(\%)\end{array}$ & $\begin{array}{l}\text { P value } \\
\text { valu }\end{array}$ \\
$\begin{array}{l}\text { Primi } \\
\text { gravida }\end{array}$ & $58(82.86)$ & $55(78.57)$ & $\begin{array}{l}113 \\
(80.71)\end{array}$ & 0.52 \\
$\begin{array}{l}\text { Multi } \\
\text { gravida }\end{array}$ & $12(17.14)$ & $15(21.43)$ & $\begin{array}{l}27 \\
(19.29)\end{array}$ & 0 \\
\hline Total & $70(100)$ & $70(100)$ & $\begin{array}{l}140 \\
(100)\end{array}$ \\
\hline
\end{tabular}

Test-chi square test

The mean gestational age of presentation of PROM was found to be 270 days \pm 7.05 .

Table 3: Gestational age incidence.

\begin{tabular}{|c|c|c|c|c|}
\hline \multirow{2}{*}{$\begin{array}{l}\text { Gestational Age } \\
\text { (weeks) }\end{array}$} & \multicolumn{2}{|l|}{$\mathbf{N}(\%)$} & \multirow{2}{*}{$\begin{array}{l}\text { Total N } \\
(\%)\end{array}$} & \multirow{2}{*}{ P-value } \\
\hline & Group A oral misoprostol & Group B intracervical PGE2 gel & & \\
\hline $37-38$ & $24(34.29)$ & $30(42.86)$ & $54(38.57)$ & \multirow{2}{*}{0.398} \\
\hline $38-40$ & $40(57.14)$ & $32(45.71)$ & $72(51.43)$ & \\
\hline More than 40 & $6(8.57)$ & $8(11.43)$ & $14(4.29)$ & \\
\hline Mean (SD) days & $270.94 \pm 7.05$ & $270.33 \pm 7.80$ & & 0.626 \\
\hline Range (days) & $259-284$ & $254-287$ & & \\
\hline
\end{tabular}

Test-chi square test 
More number of patients with term PROM entered the study with bishop score of 3, i.e. $61.43 \%$ in group A and $60 \%$ in group B.

Table 4: Admission bishop score.

\begin{tabular}{|llll|}
\hline $\begin{array}{l}\text { Admission } \\
\text { bishop } \\
\text { score }\end{array}$ & $\begin{array}{l}\text { N }(\%) \\
\text { Group A } \\
\text { oral } \\
\text { misoprostol }\end{array}$ & $\begin{array}{l}\text { Group B } \\
\text { intracervical } \\
\text { PGE2 gel }\end{array}$ & $\begin{array}{l}\text { TOTAL } \\
(\text { N\%) }\end{array}$ \\
\hline 2 & $25(35.71)$ & $15(21.43)$ & $\begin{array}{l}40 \\
(28.57)\end{array}$ \\
\hline 3 & $43(61.43)$ & $42(60)$ & $\begin{array}{l}85 \\
(60.71)\end{array}$ \\
\hline 4 & $2(2.86)$ & $13(18.57)$ & $\begin{array}{l}15 \\
(10.71)\end{array}$ \\
\hline Mean (SD) & $2.67(0.53)$ & $2.97(0.63)$ & \\
\hline Median & 3 & 3 & \\
\hline Range & $2-4$ & $2-4$ & \\
\hline
\end{tabular}

Test: Fisher's exact test

Fifty-three women $(75.73 \%)(\mathrm{n}=70)$ in the oral misoprostol group with 2 doses, $4 \mathrm{hrs}$ apart had successful cervical ripening within $8 \mathrm{hrs}$ in comparison to sixty-two women $(88.58 \%)(\mathrm{n}=70)$ in the intracervical PGE2 gel group with 2 doses, 6 hrs apart approximately $12 \mathrm{hrs}$ for successful ripening. $(\mathrm{p}=0.021)$. This result was statistically significant.

Table 5: Number of prostaglandin doses required for ripening.

\begin{tabular}{|c|c|c|c|}
\hline \multirow[b]{2}{*}{ Doses } & \multicolumn{2}{|l|}{$\mathbf{N}(\%)$} & \multirow[b]{2}{*}{ P-Value } \\
\hline & $\begin{array}{l}\text { Group A } \\
\text { oral } \\
\text { misoprostol }\end{array}$ & $\begin{array}{l}\text { Group B } \\
\text { intracervical } \\
\text { PGE2 gel }\end{array}$ & \\
\hline 1 & $\begin{array}{l}24 \\
(34.29)\end{array}$ & $\begin{array}{l}38 \\
(54.29)\end{array}$ & \multirow{4}{*}{0.021} \\
\hline 2 & $29(41.43)$ & $24(34.29)$ & \\
\hline 3 & $12(17.14)$ & $8(11.43)$ & \\
\hline 4 & $5(7.14)$ & $0(0)$ & \\
\hline
\end{tabular}

Test: Fisher's exact test
Table 6: Time interval for successful ripening (induction to active phase interval).

\begin{tabular}{|c|c|c|c|}
\hline $\begin{array}{l}\text { Time of } \\
\text { successful } \\
\text { ripening } \\
\text { (hrs) }\end{array}$ & $\begin{array}{l}\text { Group A } \\
\text { oral } \\
\text { Misoprostol } \\
\text { N }(\%)\end{array}$ & $\begin{array}{l}\text { Group B Intra } \\
\text { cervical } \\
\text { Dinoprostone } q \\
\text { N }(\%)\end{array}$ & $\begin{array}{l}\text { P- } \\
\text { value }\end{array}$ \\
\hline $0-4$ & $24(34.78)$ & $1(1.43)$ & \multirow{5}{*}{$<0.001$} \\
\hline $4-8$ & $27(39.13)$ & $37(52.86)$ & \\
\hline $8-12$ & $13(18.84)$ & $22(31.43)$ & \\
\hline $12-16$ & $5(7.25)$ & $2(2.86)$ & \\
\hline$>16$ & $1(1.42)$ & $8(11.43)$ & \\
\hline Mean (SD) & $7.84 \pm 3.64$ & $9.39 \pm 4.20$ & 0.02 \\
\hline Range & $3-16$ & $4-18$ & \\
\hline
\end{tabular}

Test-chi square test

The mean duration interval from the bishop score $<4$ to $>6$ for oral misoprostol group and intracervical Dinoprostone group was $7.84 \pm 3.64$ and $9.39 \pm 4.20$ respectively.

This result was statistically significant in showing oral misoprostol group needs shorter duration interval in successful ripening of cervix than intracervical Dinoprostone because of 4 hourly intervals.

Table 7: PROM to delivery interval.

\begin{tabular}{|llll|}
\hline $\begin{array}{l}\text { PROM to } \\
\text { delivery } \\
\text { interval }\end{array}$ & $\begin{array}{l}\text { Group A oral } \\
\text { Misoprostol }\end{array}$ & $\begin{array}{l}\text { Group B Intra } \\
\text { cervical PGE2 }\end{array}$ & $\begin{array}{l}\text { P- } \\
\text { value }\end{array}$ \\
\hline$>12$ hours & $33(52.38)$ & $34(58.62)$ & 0.490 \\
\hline (12 hours & $30(47.62)$ & $24(41.38)$ & \\
\hline $\begin{array}{l}\text { Mean (SD) } \\
\text { (hours) }\end{array}$ & $12.60 \pm 3.78$ & $14.66 \pm 4.08$ & \\
\hline $\begin{array}{l}\text { Range (hours) } \\
\text { Re-24 }\end{array}$ & $8-24$ & 0.005 \\
\hline
\end{tabular}

The mean time duration interval from PROM to vaginal delivery in both groups were comparable i.e. $12.60 \pm 3.78$ hrs versus $14.66 \pm 4.08$ hours. Results shows that $55.56 \%$ of Group A delivered vaginally in $<12$ hours, in comparison to $44.44 \%$ of Group B.

Table 8: Incidence of oxytocin augmentation.

\begin{tabular}{|c|c|c|c|c|}
\hline \multirow{2}{*}{ Oxytocin augmentation } & \multicolumn{2}{|l|}{$\mathbf{N}(\%)$} & \multirow{2}{*}{ Total } & \multirow{2}{*}{$\begin{array}{l}P \\
\text { value }\end{array}$} \\
\hline & Group A oral misoprostol & Group B Intracervical PGE2 gel & & \\
\hline Yes & $33(47.14)$ & $48(68.57)$ & $81(57.85)$ & \\
\hline No & $37(52.86)$ & $22(31.43)$ & $59(42.14)$ & 0.010 \\
\hline Total & $70(100)$ & $70(100)$ & $140(100)$ & \\
\hline
\end{tabular}

Test-chi square test

It was observed that more of PGE2 gel group patients $(68.57 \%)$ needed oxytocin in comparison to $(47.14 \%)$ in oral misoprostol group.
Out of 140 cases, 121 patients had vaginal delivery, Oral misoprostol group had $95.24 \%$ and intracervical PGE2 gel had $94.83 \%$. 
Table 9: Mode of delivery.

\begin{tabular}{|c|c|c|c|c|}
\hline & $\begin{array}{l}\text { Group A oral Misoprostol } \\
\text { N }(\%)\end{array}$ & $\begin{array}{l}\text { Group B intra cervical } \\
\text { Dinoprostone gel } \\
\text { N }(\%)\end{array}$ & P-value & \\
\hline Vaginal & 63 & 58 & \multirow{4}{*}{0.846} & \\
\hline Spontaneous & $60(95.24)$ & $55(94.83)$ & & \\
\hline Forceps & $1(1.59)$ & $2(3.45)$ & & \\
\hline Vacuum & $2(3.17)$ & $1(1.72)$ & & \\
\hline \multirow{2}{*}{ LSCS } & $\mathbf{N}(\%)$ & & Total & P- \\
\hline & Group A oral misoprostol & Group B intracervical PGE2 gel & rotal & value \\
\hline Yes & $7(10)$ & $12(17.14)$ & $19(13.57)$ & \multirow{3}{*}{0.217} \\
\hline No & $63(90)$ & $58(82.86)$ & $121(86.43)$ & \\
\hline Total & $70(100)$ & $70(100)$ & $140(100)$ & \\
\hline Fetal distress & $4(57.14)$ & $6(50.00)$ & & \multirow{2}{*}{0.570} \\
\hline Arrest disorder & $3(42.86)$ & $6(50.00)$ & & \\
\hline
\end{tabular}

Test-chi square test

Table 10: Prostaglandin side effects.

\begin{tabular}{|c|c|c|c|c|}
\hline \multirow{2}{*}{ Prostaglandin side effects } & \multicolumn{2}{|l|}{$\mathbf{N}(\%)$} & \multirow{2}{*}{ Total } & \\
\hline & Group A oral misoprostol & Group B intracervical PGE2 gel & & \\
\hline Tachysystole & $1(50)$ & $0(0)$ & $1(50)$ & \\
\hline Hyperstimulation & $1(50)$ & $0(0)$ & $1(50)$ & \\
\hline Total & $2(100)$ & $0(0)$ & $2(100)$ & \\
\hline Vomiting & Group A oral misoprostol & Group B intracervical PGE2 gel & Total & P-value \\
\hline Yes & $8(11.43)$ & $5(7.14)$ & $13(9.29)$ & 0.382 \\
\hline No & $62(88.57)$ & $65(92.86)$ & $127(90.71)$ & \\
\hline Total & $70(100)$ & $70(100)$ & $140(100)$ & \\
\hline
\end{tabular}

Test-chi square test

Table 11: Apgar score.

\begin{tabular}{|c|c|c|c|c|}
\hline \multirow{2}{*}{$\begin{array}{l}\text { APGAR } \\
\text { score-1 } \\
\text { minutes } \\
<7\end{array}$} & \multicolumn{2}{|l|}{$\mathbf{N}(\%)$} & \multirow[b]{2}{*}{ Total } & \multirow[b]{2}{*}{$\begin{array}{l}\text { P- } \\
\text { value }\end{array}$} \\
\hline & $\begin{array}{l}\text { Group A } \\
\text { oral } \\
\text { misoprostol }\end{array}$ & $\begin{array}{l}\text { Group B } \\
\text { intracervical } \\
\text { PGE2 gel }\end{array}$ & & \\
\hline No & $\begin{array}{l}68 \\
(97.14)\end{array}$ & $\begin{array}{l}68 \\
(97.14)\end{array}$ & $\begin{array}{l}136 \\
(97.14)\end{array}$ & \multirow{2}{*}{0.690} \\
\hline Yes & $\begin{array}{l}2 \\
(2.86)\end{array}$ & $\begin{array}{l}2 \\
(2.86)\end{array}$ & $\begin{array}{l}4 \\
(2.86)\end{array}$ & \\
\hline Total & $\begin{array}{l}70 \\
(100)\end{array}$ & $\begin{array}{l}70 \\
(100)\end{array}$ & $\begin{array}{l}140 \\
(100)\end{array}$ & \\
\hline
\end{tabular}

Test-chi square test

Table 12: NICU admission-due to neonatal sepsis.

\begin{tabular}{|c|c|c|c|c|}
\hline \multirow[b]{2}{*}{$\begin{array}{l}\text { NICU } \\
\text { admission }\end{array}$} & \multicolumn{2}{|c|}{$\mathbf{N}(\%)$} & \multirow[b]{2}{*}{ Total } & \multirow[b]{2}{*}{$\begin{array}{l}\text { P- } \\
\text { value }\end{array}$} \\
\hline & $\begin{array}{l}\text { Group A } \\
\text { oral } \\
\text { misoprosto }\end{array}$ & $\begin{array}{l}\text { Group B } \\
\text { intracervical } \\
\text { PGE2 gel }\end{array}$ & & \\
\hline No & $\begin{array}{l}68 \\
(97.14)\end{array}$ & $\begin{array}{l}67 \\
(95.71)\end{array}$ & $\begin{array}{l}135 \\
(96.43)\end{array}$ & \multirow{2}{*}{0.649} \\
\hline Yes & $\begin{array}{l}2 \\
(2.86)\end{array}$ & $\begin{array}{l}3 \\
(4.29)\end{array}$ & $\begin{array}{l}5 \\
(3.57)\end{array}$ & \\
\hline Total & $\begin{array}{l}70 \\
(100)\end{array}$ & $\begin{array}{l}70 \\
(100)\end{array}$ & $\begin{array}{l}140 \\
(100)\end{array}$ & \\
\hline
\end{tabular}

Test: Fisher's exact test
2 patients in oral misoprostol group had hyperstimulation which was controlled with subcutaneous terbutaline injection. Total of 4 babies 2 in each group (2.86\%) had low APGAR score due to reasons like respiratory distress, transient tachypnoea of new born, prolonged labour, operative delivery.

5 cases with neonatal sepsis were noted however none correlated with maternal vaginal swab culture.

Table 13: Birth weight.

\begin{tabular}{|c|c|c|c|}
\hline \multirow[b]{2}{*}{$\begin{array}{l}\text { Birth } \\
\text { weight } \\
\text { (kg) }\end{array}$} & \multicolumn{2}{|l|}{$\mathbf{N}(\%)$} & \multirow[b]{2}{*}{ Total } \\
\hline & $\begin{array}{l}\text { Group A } \\
\text { oral } \\
\text { misoprostol }\end{array}$ & $\begin{array}{l}\text { Group B } \\
\text { intracervical } \\
\text { PGE2 gel }\end{array}$ & \\
\hline Less than 3 & $25(35.71)$ & $21(30.00)$ & $46(32.86$ \\
\hline $3.1-3.5$ & $35(50.00)$ & $31(44.29)$ & $66(47.14$ \\
\hline More than 3.5 & $10(14.29)$ & $18(25.71)$ & $28(20.00$ \\
\hline Total & $70(100)$ & $70(100)$ & $140(100)$ \\
\hline Mean (SD) (k & $3.15 \pm 0.28$ & $3.23 \pm 0.32$ & $P$ value \\
\hline Range & $2.59-3.85$ & $2.67-3.87$ & 0.116 \\
\hline
\end{tabular}

No statistical significant result seen in terms of birth weight of the baby in both the groups. 


\section{DISCUSSION}

Various trials have shown that misoprostol is an effective agent for cervical ripening. The admission Bishop score plays an important role in effective cervical ripening. In the present study we had a mean admission BS as 3 in both the study groups. Hence study results obtained likewise was well interpreted. The dose of oral misoprostol was repeated every 4 hourly in comparison to intracervical PGE2 gel that has been recommended to be repeated every 6 hourly. Hence when low dose oral misoprostol was used, present study clearly states that 2nd dose can be repeated within 4 hours if effective cervical ripening did not occur and hence total of 53 patients in the oral misoprostol group had successful ripening in comparison to 62 patients in group $B$ at the end of 8 hours and 12 hours respectively. This result was statistically significant in the present study $(\mathrm{P}=0.021)$.

Comparison between the number of doses were not evaluated in study conducted by Nagpal MB et al, however, Colon et al and Jindal et al in his study (step wise increase of $50 \mathrm{mcg}$ oral misoprostol every 4 hourly versus $25 \mathrm{mcg}$ vaginal misoprostol) with unfavorable cervix , but intact membranes showed that minimum number of PGE1 was required by vaginal misoprostol group when repeated every 4 hourly, concluding that vaginal misoprostol was more efficacious cervical ripener than oral PGE1 but at the cost of increase uterine abnormalities and increase ceasarean section rates. ${ }^{11-13}$

In the present study the induction to active phase (ITA) interval also had statistically significant outcome ( $P$ $<0.001)$. It was observed that at the end of 8 hours total of $74.51 \%$ in group A had successful ripening and entered the active labour than $54.29 \%$ in group B. The mean time interval was $7.84 \pm 3.64$ hours and $9.39 \pm 4.20$ hours in group A and B respectively.

Ngai et al (200 mcg single oral dose of misoprostol versus placebo) and Ayaz et al (50 mcg oral misoprostol versus conservative managemental in term PROM patients) reported ITA phase interval of $3.3 \pm 1.8$ hours versus $9.2 \pm 3.9(\mathrm{P}<0.01)$ and $(9.6$ hours versus 11.6 hours, $\mathrm{P}<0.001)$ respectively. ${ }^{14,15}$

Nagpal MB et al reported ITA phase interval (420 \pm 244 min $50 \mathrm{mcg}$ oral misoprostol group and $790 \pm 284 \mathrm{~min}$ in PGE2 gel group) $(\mathrm{P}<0.001)$.

Present study also measured the time interval from PROM to delivery. The mean PROM to delivery interval was $12.60 \pm 3.78$ hours in group A versus $14.66 \pm 4.08$ hours in group $\mathrm{B}(\mathrm{P}<0.01)$. Ngai et al in his study with $200 \mathrm{mcg}$ oral misoprostol showed similar results where PROM to delivery interval was $7.5 \pm 6$ hours versus $16.2 \pm 6.3$ hours in placebo group.

Hoffmann RAM et al studied in term PROM using further low dose of $100 \mathrm{mcg}$ oral misoprostol every 6 hourly in comparison to placebo and the result was the same with oral misoprostol requiring 7.5 hours in comparison to placebo $25 \mathrm{hrs}(\mathrm{P}<0.001)$ for PROMdelivery interval. ${ }^{16}$

Nagpal MB et al showed similar and efficient results with $50 \mathrm{mcg}$ oral misoprostol every 4 hourly in comparison with PGE2 gel (615 min versus $1070 \mathrm{~min})(\mathrm{P}<0.001)$.

Al Hussaini TK et al reported a significant shorter interval of PROM to delivery $60 \%$ versus $35.4 \%$ using $100 \mathrm{mcg}$ oral misoprostol every 6 hourly in comparison to iv oxytocin with a statistically significant result $(\mathrm{P}<0.001){ }^{17}$

Ayaz et al compared $50 \mathrm{mcg}$ oral misoprostol every 4 hourly versus conservative management in term PROM patients and showed similar results of misoprostol reducing PROM to delivery interval (14.8 hours versus 17 hours, $\mathrm{P}<0.001)$.

In the present study we observed that $47.14 \%$ patients in oral misoprostol group required oxytocin whereas $68.57 \%$ in intracervical PGE2 gel required oxytocin. This result was statistically significant $\mathrm{P}<0.001$. Oral misoprostol has an added benefit of being an oxytocic too, hence in patients with PROM where to avoid chorioamnionitis the PROM to delivery interval has to be shorten, it can be very well acceptably used.

Hence by inducing the patient we did not increase the ceasarean section rates, infact the rate of ceasarean is significantly reduced because of effective cervical ripening.

However, it is important to note that the incidence of maternal complications is significantly decreased when used low dose of oral misoprostol $(25 \mathrm{mcg})$ as evident from the other studies conducted by various other authors without altering the efficacy of oral misoprostol in cervical ripening. No significant outcome was encountered in terms of neonatal complication.

\section{CONCLUSION}

Present study states that from efficacy point of view, the $25-\mathrm{mcg}$ oral misoprostol given every 4th hourly with maximum of 4 doses each is as efficacious as $0.5 \mathrm{mg}$ intracervical PGE2 gel every 6 hourly with maximum of 3 doses each in ripening the cervix in term PROM patients.

In terms of safety, oral misoprostol is not devoid of its abnormal uterine actions (like hyperstimulation, tachysystole) even with the lowest dose but can be very well used with caution because of 4 hourly dosing intervals.

Number of doses of prostaglandin required in oral misoprostol group is significantly less than the number of 
doses required in intracervical PGE2 gel group. Hence the time required for successful ripening was shorter in oral misoprostol group in comparison to intracervical PGE2 gel group thereby reducing the time interval from rupture membranes to active labour and rupture membranes to delivery interval.

Patients satisfaction with oral misoprostol group for active management in term PROM in terms of shorter admission (onset of PROM) to delivery interval, shorter PROM to successful cervical ripening interval, lesser vaginal intervention has been significantly appreciated.

Misoprostol also has an added benefit of inducing uterine contractions along with cervical ripening property thereby helping the patient to go into spontaneous labour earlier than intracervical PGE2 gel group of patients. Hence the need for oxytocin augmentation was also significantly less in oral misoprostol group.

Maternal outcomes in terms of modes of delivery in both the study group was not significantly different, hence concluding that neither drug has any significant influence in the mode of delivery per se. Prostaglandins side effects like nausea vomiting was well tolerated in both the study groups.

Study results in terms of neonatal outcomes - neonatal sepsis, NICU admission and Birth weight was not affected by route of cervical ripening agents used in our study.).

Funding: No funding sources Conflict of interest: None declared

Ethical approval: The study was approved by the Institutional Ethics Committee

\section{REFERENCES}

1. Mozurewich E. Management of premature rupture of membrane at term: an evidence based approach. Clin Obstet Gynaecol. 1999;42:749-56.

2. Shetty A, Stwart G, Stewart G, Rice P, Danielian P, Templeton A. Active management of term prelabour rupture of membranes with oral misoprostol. $\mathrm{Br} \mathrm{J}$ Obstet Gynaecol. 2002;109:1354-8.

3. Edwards RK, Richards DS. Preinduction cervical assessment. Clin Obstet Gynecol. 2000;43:440-6.

4. Royal College of Obstetricians and Gynaecologists. Induction of Labour. Guideline. No. 9. London, UK: RCOG Press. 2001.

5. Wing DA. Labor induction with misoprostol. Am J Obstet Gynecol. 1999;181:339-45.

6. Zieman M, Fong SK, Benowitz NL, Banskter D, Darncy PD. Absorption kinetics of misoprostol with oral or vaginal administration. Obstet Gynecol. 1997;90:88-92.

7. Butt KD, Bennett KA, Crane JMG, Hutchens D, Young DC. Randomized comparison of misoprostol and oxytocin for labour induction in term prelabour membranes rupture. Obstet Gynecol. 1999;94:994-9.

8. Sanchez-Ramos L, Kaunitz AM, Gaudier FL, Delke I. Cervical ripening and labor induction with a controlledrelease dinoprostone vaginal insert: a meta-analysis. Obstet Gynecol. 1999;94:873-83.

9. Chong YS, Su LL, Arulkumaran S. Misoprostol: a quarter century of use, abuse, and creative misuse. Obstet Gynecol Surv. 2004;59:128-40.

10. Wing DA, American College of Obstetricians and Gynecologists. Induction of Labor. ACOG Committee Opinion no 10. Washington, DC: ACOG. 1999.

11. Monika NB, Chitra R, Saili A. Oral misoprostol versus prostaglandin E2 gel for active management of premature rupture of membranes at term. Int $\mathbf{J}$ Gynecol Obstet. 2009;106:23-6.

12. Iris C, Kathya C, Kennith H, Maurice DL, Mark TM. Prospective randomized clinical trial of inpatient cervical ripening with stepwise oral misoprostol versus vaginal misoprostol. Am J Obstet Gynecol. 2005; 192:747-52.

13. Jindal P, Avasthi K, Kaur M. A comparison of vaginal versus oral misoprostol for induction of labour-double blind randomized trial. $\mathrm{J}$ Obstet Gynecol India. 2011:61(5):538-42.

14. Ngai SW, To WK, Lao T, Ho PC. Cervical priming with oral misoprostol in pre-labor rupture of membranes at term. Obstet Gynecol. 1996;87:923-6.

15. Aqueela A, Shazia S, Usman FM, Fayaz A, Ali BL, Iftikhar A. Prelabour rupture of membranes at term in patients with unfavorable cervix: active versus conservative management. Taiwan J Obstet Gynecol. 2008;47(2):192-6.

16. Al-Hussaini TK, Abdel-Aal SA, Youssef MA. Oral misoprostol versu intravenous oxytocin for labor induction in women with prelabor rupture of membranes at term. Int $\mathbf{J}$ Gynecol Obstet. 2003;82(1):73-5.

17. Hoffman RA, Anthony J, Fawcus S. Oral misoprostol versus placebo in the management of prelabor rupture of membranes at term. Int $\mathbf{J}$ Gynecol Obstet. 2001;72:215-21.

18. Levy R, Vaisbuch E, Furman B, Brown D, Volach V, Hagay ZJ. Induction of labor with oral misoprostol for premature rupture of membranes at term in women with unfavorable cervix: a randomized, double-blind, placebo-controlled trial. J Perinat Med. 2007;35(2):1269.

Cite this article as: Nadar AN, Sirisha PSRNS.

Comparative study of oral PGE 1 and intracervical PGE2 gel for pre-induction cervical ripening in prelabour rupture of membranes $>37$ weeks gestational age. Int J Reprod Contracept Obstet Gynecol 2018;7:1801-7. 